\title{
DIREITO PENAL NA ERA PÓS-DEMOCRÁTICA: INTERVENÇÃO FEDERAL, PRESUNÇÃO DE INOCÊNCIA E OPINIÃO PÚBLICA
}

\author{
RAVAGNANI, Christopher Abreu ${ }^{1}$ \\ NEVES, Bruno Humberto ${ }^{2}$ \\ RAVAGNANI, Mariana Spaggiari Alcântara ${ }^{3}$
}

\begin{abstract}
RESUMO: O presente artigo tem como objetivo analisar a problemática da relativização dos direitos e garantias fundamentais, em face da expansão do poder punitivo estatal, através de revisão bibliográfica crítica. Para tanto, argumentaremos sobre a relevância do projeto constitucional do Estado Democrático de Direito, com o fito de limitar os espaços de arbítrio e opressão, a fím de evitar novos holocaustos, em especial o papel contramajoritário do Poder Judiciário de assegurar as regras do jogo. Os resultados demonstram que em nome do combate ao inimigo comum, os direitos fundamentais são afastados, sob fundamentos de apelo populista.
\end{abstract}

Palavras-chave: Autoritarismo. Senso comum. Opinião Pública.

\section{PENAL LAW IN THE POST-DEMOCRATIC AGE: FEDERAL INTERVENTION, PRESUMPTION OF INNOCENCE AND PUBLIC OPINION}

SUMMARY: This article aims to analyze the problematic of the relativization of fundamental rights and guarantees, in the face of the expansion of state punitive power, through a critical bibliographic review. To do so, we will argue about the relevance of the constitutional project of the Democratic State of Law, in order to limit arbitrary and oppressive spaces, in order to avoid new holocausts, especially the counter majoritarian role of the Judiciary to ensure the rules of the game. The results show that in the name of combating the common enemy, fundamental rights are removed on the basis of populist appeal.

Keywords: Authoritarianism. Common sensation. Public opinion.

\section{INTRODUÇÃO}

No momento em que a Constituição Federal (CF/88) completa 30 anos, os direitos individuais fundamentais se estremecem perante uma política de "enfrentamento" à violência, "priorizando-se" a derrota do inimigo comum ${ }^{4}$ (violência) aos direitos e garantias fundamentais. A expansão do Sistema Penal assume o papel de ator principal na política pública brasileira e seus efeitos nefastos se tornam visíveis no aumento exacerbado da população carcerária, ao ponto que direitos fundamentais vivem momento de relativização.

$\mathrm{Na}$ esteira disso, exsurge uma mentalidade de matriz inquisitória, no qual as regras processuais e o compromisso constitucional de zelar pelo Estado Democrático de Direito são postos em segundo plano.

\footnotetext{
${ }^{1}$ Mestre em Direito pela UNESP - Universidade Estadual Paulista "Júlio de Mesquita Filho". Professor de Direito na Faculdade Dr. Francisco Maeda

${ }^{2}$ Graduado em Direito pela Faculdade Dr. Francisco Maeda. Advogado Criminalista.

${ }^{3}$ Graduada em Direito pela Faculdade de Direito de Franca - FDF

${ }^{4}$ Expressão de Zaffaroni (2017), o qual adverte sobre a relativização dos direitos fundamentais dos acusados em detrimento da expansão do poder punitivo estatal.
} 
Os direitos fundamentais - limites rígidos ao exercício do poder - são afastados sob "fundamentos" de apelo populista.

Neste cenário, princípios e garantias fundamentais, como: dignidade da pessoa humana; liberdade; presunção de inocência; tornam-se descartáveis, alcançando até mesmo o Poder Judiciário guardião (deveria ser) dos direitos e garantias fundamentais, mas que contaminado por discursos de ódio forjados na opinião pública (senso comum), vê-se inserido como órgão do aparelho repressivo estatal, verificandose uma verdadeira confusão (unificação) entre acusador-julgador, típica do período inquisitivo. (RAVAGNANI; POPOLIM, 2018).

A partir dessas considerações, através de uma revisão bibliográfica crítica, o artigo teve como objetivo analisar a relativização de direitos e garantias fundamentais no campo da denominada política criminal brasileira, em face do agigantamento do aparelho punitivo estatal, adotando-se a terminologia "Estado Pós-Democrático" de Rubens Casara (2017) para designar o atual cenário brasileiro.

\section{O ESTADO DEMOCRÁTICO DE DIREITO}

Nos termos do preâmbulo da Constituição de 1988, foi instituído um Estado Democrático destinado a assegurar os seguintes valores supremos de uma sociedade pluralista e comprometida, na ordem interna e internacional, com a solução pacífica das controvérsias, o exercício dos direitos sociais e individuais, a liberdade, a segurança, o bem-estar, o desenvolvimento, a igualdade e a justiça. (LENZA, 2009).

Por Estado Democrático de Direito, assenta Rubens Casara (2017), entende-se um estado constitucional, em que os direitos e as garantias fundamentais não podem ser afastados ao desejo dos agentes estatais, assim, o poder, além de limitado, deve exercer-se de forma democrática e dirigido à concretização do projeto constitucional, até para aqueles que podem ser tidos por indesejáveis pela população.

A configuração do Estado Democrático de Direito não significa apenas unir formalmente os conceitos de Estado Democrático e Estado de Direito. Consiste, segundo José Afonso da Silva (2016), na criação de um conceito novo, que leva em conta os conceitos dos elementos componentes, mas os supera na medida em que incorpora um componente revolucionário de transformação do status quo, não como mera promessa de organizar tal Estado, pois a Constituição aí já o está proclamando e fundando.

A constitucionalidade é da essencialidade do Estado Democrático de Direito, assegurando um sistema de direitos fundamentais individuais, coletivos, sociais e culturais; o que pressupõe, para o Poder Judiciário, a independência do judicial como uma garantia para o cidadão. Nessa toada, ao Judiciário compete a defesa incondicional e a garantia efetiva dos direitos fundamentais da pessoa humana, para que a Constituição Federal não se torne letra morta. (BOUJIKIAN, 2018).

Assim, a noção de Estado Democrático de Direito está, conforme Lenio Streck (2008), indissociavelmente ligada à realização dos direitos fundamentais, agregando a construção das condições de possibilidade para suprir as lacunas das etapas anteriores, representadas pela necessidade do resgate das promessas da modernidade, tais como igualdade, justiça social e a garantia dos direitos humanos fundamentais.

Nessa perspectiva, segundo Magalhaes Filho (2004, p. 104):

As bases do Estado Democrático de Direito são a soberania do povo, expressa na manifestação da vontade popular, e a dignidade humana, consagrada na enunciação dos direitos fundamentais. Em razão desse segundo pilar, evidencia-se não apenas o plano político, mas também nas dimensões econômica, social e cultural. Na esfera econômica, o trabalhador, parte mais fraca nas relações laborais, deve ser protegido juridicamente 
para que não seja explorado por aquele que dispõe de vantagem econômica, isto é, pelo empregador. Na perspectiva social, exige-se justiça social, sendo esta não apenas a justiça distributiva que estabelece que cada um deve receber de acordo com os seus méritos ou capacidades, mas também aquela que proclama que deve ser dado a cada um segundo as suas necessidades, ou seja, as necessidades humanas primordiais devem ser atendidas. Finalmente, no plano cultural, exige-se que a todos seja assegurada a educação.

Desse modo, tem-se a noção de que o Estado Democrático de Direito tem o objetivo de não apenas garantir no plano legal o exercício de direitos individuais e sociais, mas efetivamente promover os direitos fundamentais. Logo, o Poder Judiciário passa a ter fundamental papel na efetivação dos direitos fundamentais, de modo que se faz necessário assumir seu caráter compromissório em suprir as promessas da modernidade.

Com o Estado Democrático de Direito, defende Casara (2017), buscou-se impedir novos movimentos de orientação autoritária que levassem à ampliação dos poderes do Estado, máxime do poder penal, instrumental que serve ao surgimento de neofascismos, e à minimização das liberdades individuais.

Inquestionavelmente, os valores de um Estado Democrático de direito devem ser observados pelos estados, uma vez que se traduzem em comandos constitucionais inseridos dentro dos respectivos ordenamentos jurídicos. (GOMES; MARQUES, 2017). Nesta perspectiva, o princípio da dignidade da pessoa humana é um valor suprapositivo, pois a dignidade da pessoa humana é o núcleo essencial de todos os direitos fundamentais. Assim, uma vez violado um direito fundamental, significa dizer que a própria dignidade da pessoa humana foi transgredida. (MAGALHAES FILHO, 2004).

Neste sentido, a figura do Estado Democrático de Direito visa limitar os espaços de arbítrio e opressão, a fim de evitar novos holocaustos, constituído em um tipo de ordenamento no qual o poder público está rigidamente limitado e vinculado à lei adequada à normatividade constitucional, tanto no plano substancial - relativo aos conteúdos relevantes - quanto no plano processual/procedimental relativo às formas processualmente vinculantes. (CASARA, 2017).

Desta feita, mais do que garantir procedimentos democráticos, a Constituição Federal deve ser interpretada e efetivada no seu sentido substancial, conforme defende Lenio Streck (2008, p. 121):

A Constituição ainda deve "constituir-a-ação", mormente porque, no Brasil, nunca constituiu. No texto da Constituição de 1988, há um núcleo essencial, não cumprido, contendo um conjunto de promessas da modernidade, que deve ser resgatado (o ideal moral transforma-se em obrigação jurídica). O problema é que, em países como o Brasil, formou-se um "silêncio eloquente" acerca do significado da Constituição, naquilo que ela tem de "norma diretiva fundamental". Com isso se explica parte da crise constitucional brasileira, isto é, a pouca importância que se tem dado ao direito constitucional e ao próprio texto constitucional, mormente se levarmos em conta o novo modelo de Estado Democrático de Direito, estabelecido pela Constituição de 1988, que seguiu os modelos de Constituições dirigentes do segundo pós-guerra. Numa palavra: sob o manto de uma "baixa constitucionalidade", olvidou-se o constituir da Constituição; mas, muito pior do que o silêncio é não prestarmos atenção nele.

Logo, a efetividade da Constituição - seu papel dirigente e compromissório na efetivação dos direitos humanos fundamentais - é, pois, agenda obrigatória de todos preocupados com a transformação de uma sociedade como a brasileira, que, em mais de cinco séculos de existência, produziu pouca democracia e muita miséria, fatores geradores de violências institucionais (veja-se a repressão produzida pelos aparelhos do Estado) e sociais (veja-se o grau exacerbado da criminalidade). (STRECK, 2008).

O Estado Democrático de Direito, portanto, não se contenta com a democracia meramente formal, mesmo a maioria da população não pode afastar direitos fundamentais. Cabe ao Poder Judiciário a função de garante do Estado Democrático de Direito e, portanto, das "regras do jogo." Assim, não deve existir 
espaço para qualquer espécie de populismo judicial, mesmo o desejo de maiorias de ocasião forjadas (deformadas) pelos meios de comunicação de massa, os órgãos jurisdicionais não podem violar a Constituição para agradar a opinião pública. (CASARA, 2015).

A democracia que o Estado Democrático de Direito realiza, como bem assenta Kenarik Boujikian (2018), há de ser um processo de convivência social numa sociedade livre justa e solidária, porque pressupõe o diálogo entre opiniões, pensamentos divergentes, com reconhecimento de direitos individuais, políticos e sociais, que supere as desigualdades sociais e regionais. Em suma, o objetivo é a efetivação dos direitos fundamentais da pessoa humana, verdadeiro obstáculo ao exercício do poder.

O Estado Democrático de Direito, portanto, representa autêntico óbice ao desenvolvimento do autoritarismo, condicionando o comportamento do poder público ao respeito e observância dos direitos e garantias fundamentais, mormente a dignidade da pessoa humana, sustentáculo da unidade constitucional.

\section{DIREITO PENAL NA ERA PÓS-DEMOCRÁTICA: INTERVENÇÃO FEDERAL, PRESUNÇÃO DE INOCÊNCIA E OPINIÃO PÚBLICA}

A Constituição Federal brasileira apesar de possuir como pilares os direitos e garantias fundamentais, cláusulas pétreas, as quais não admitem - não deveriam admitir - relativização, vem sofrendo, diuturnamente, os mais diversos tipos de ataques, mormente no campo da denominada política criminal, ressuscitando o processo penal à lógica medieval.

Infelizmente essa matriz autoritária - relativização dos direitos e garantias fundamentais - segue vigente, mesmo no período pós-Constituição Federal de 1988, e permanece influenciando a prática forense. Sintomas claros são a relativização das formas, preponderância dos elementos do inquérito, ordem pública, banalização da prisão cautelar, mitigação do nível de exigência probatória para condenação, dentre outros sintomas claros e evidentes que não condizem com os ideais democráticos de nossa Constituição. (ROSA; OLIVEIRA, 2018).

Os sintomas da banalização da prisão - afastando-se o direito de liberdade - refletem diretamente no contingente carcerário. Em junho de 2016, a população carcerária brasileira atingiu a marca de 726,7 mil presos, mais que o dobro de 2005, quando o Brasil tinha 361,4 mil presos, tornando-se o terceiro país do mundo no ranking do aprisionamento mundial. (CARTA CAPITAL, 2018). A análise do perfil carcerário aponta para uma maioria de jovens $(55,00 \%$ da população privada de liberdade tem até 29 anos), composta pela maioria de negros (64\% da população presa), e para uma população com precário acesso à educação (apenas 9,5\% concluíram o ensino médio, enquanto a média nacional gira em torno de $32 \%$, bem como de 1\% dos presos possuem graduação). (MINISTÉRIO DA JUSTIÇA, 2017).

Contudo, não há ao menos um indicativo de que o aprisionamento desse corpo social esteja produzindo qualquer resultado benéfico no refreamento da violência, veja-se que conforme o último levantamento do INFOPEN (MINISTÉRIO DA JUSTIÇA, 2017), o número de detentos dobrou nos últimos 10 anos. Observa-se, dessa forma, que a expansão (a qualquer custo) do poder punitivo, não soluciona o problema da violência, mas reproduz ainda mais violência no sistema carcerário. (RAVAGNANI; NEVES; ITO, 2017).

Outrossim, no campo das liberdades públicas, conforme constata Casara (2017), as inviolabilidades tornam-se cada vez mais seletivas, de modo que apenas o domicílio de alguns é inviolável, como demonstram os mandados de busca e apreensão "coletivos", expedidos para serem cumpridos em favelas ou periferias; apenas a liberdade de alguns é inviolável, como revelam prisões e conduções coercitivas em desconformidades com os requisitos legais; apenas a intimidade de alguns é inviolável, como se percebe dos vazamentos seletivos de interceptações telefônicas. 
Por este ângulo, a desconexão do Poder Judiciário, com o propósito constitucional, vem de suas decisões e posturas, consoante Boujikian (2018):

Apenas a título de exemplo, menciono alguns episódios e situações que foram divulgados e que escancaram violações à princípios fundamentais pelo judiciário, embora deva ser o ente último a salvaguardá-los. Vejamos: - O grande número de conduções coercitivas realizadas ao arrepio da lei. Existem regras claras para que ela possa ser realizada. Se não se encontra nas hipóteses taxativas, o que temos é uma prisão, um cerceamento da liberdade do ir e vir, realizada ao arrepio da lei. A condução coercitiva do acusado só seria cabível depois de intimação prévia, não cumprida. - A violação de norma constitucional referente à divulgação de diversas escutas telefônicas, de várias pessoas, feitas aos borbotões, culminando com a violação do juiz Sérgio Moro ao divulgar uma ligação da presidência da república, ao ex-presidente Lula, em absoluta afronta à ordem jurídica. - O impedimento de Lula, candidato à presidência da república, de dar entrevistas ao arrepio ao sistema eleitoral e ao direito de manifestação de todas as pessoas detidas. - A "criminalização" dos movimentos populares, aqui entendido em seu sentido amplo, encontra no judiciário a sua maior ferramenta, seja na impunidade dos homicídios praticados pelos algozes dos defensores de direitos humanos, seja no cerceamento das manifestações, que são o exercício da liberdade de expressão, pedra fundamental da democracia. No mês de agosto de 2018, magistrados proibiram manifestações favoráveis ao presidente Lula em dois shoppings centers, no Rio de Janeiro e Salvador. - O sério problema da concentração das decisões, nas mãos de um ministro, na medida que cada um resolve quando coloca o processo para julgamento e depois é a presidenta do Supremo Tribunal Federal (STF) quem decide se o processo vai ou não entrar para pauta. (BOUJIKIAN, 2018, [s/p]).

Neste sentido, conforme demonstra Boujikian (2018), os ataques aos direitos e garantias fundamentais previstos em nossa constituinte podem ser praticados, até mesmo, por aquele Poder que deveria zelar efetividade do texto constitucional. Os direitos fundamentais - que, antes, serviam como gramática positivada dos direitos humanos e estratégia de realização da dignidade da pessoa humana tornam-se descartáveis, ao passo que os discursos e as práticas autoritárias tornam-se mercadorias atrativas, que moldam a "justiça" ao gosto da opinião pública, mesmo que para isso seja necessário suprimir direitos ou reforçar preconceitos e perversões. (CASARA, 2017).

Neste momento em que o Estado policialesco ganha força, faz-se necessário o alerta para os riscos decorrentes do autoritarismo na utilização indevida das Forças Armadas em tarefas de segurança pública, como a intervenção federal no Estado do Rio de Janeiro, Decreto 9.288/2018, com a finalidade de "pôr termo" a grave comprometimento da ordem pública local.

A Constituição Federal deixa claro, não por acaso, que a segurança pública é exercida pelas forças policiais. Assim, atribui à polícia federal e civil à investigação de infrações penais (polícia investigativa) e às funções de auxílio ao Poder Judiciário no cumprimento de determinações judiciais (polícia judiciária). Lado outro, o policiamento ostensivo e a preservação da ordem e da segurança pública competem à polícia militar.

Logo, verifica-se que as tarefas de segurança pública são atribuídas aos órgãos policiais (art. 144, $\mathrm{CF} / 88$ ), destacando-se sua natureza eminentemente civil, o que difere, inexoravelmente, das funções reservadas às Forças Armadas voltadas para ameaças externas e guerras, sobretudo por serem abordadas em capítulo distinto pela Constituição Federal (art. 142, CF/88), e não integrar os órgãos de segurança pública (polícia federal, civil e militar), razão a qual sua utilização, em tarefas de segurança pública, é manifestamente inconstitucional.

Conforme bem pontua Maria Lucia Karam (2018) o Decreto 9.288/2018 parece trazer apenas uma reiteração de já desgastadas e sempre inconstitucionais operações militares anteriormente desenvolvidas notadamente no Rio de Janeiro. 
Desde 1994, com a chamada Operação Rio, aos mais recentes novembro de 2010, quando se iniciou a televisada ocupação militar nas favelas da Vila Cruzeiro e do Complexo do Alemão, ou abril de 2014, em que uma força composta de militares da Brigada Paraquedista do Exército, fuzileiros navais, tanques, caminhões, jipes, carros anfíbios e outras viaturas blindadas ocupava o complexo de favelas da Maré, sem contar outras operações pontuais menos duradouras e/ou espetaculares, variados governos federais têm enviado as Forças Armadas ao Rio de Janeiro para, desviadas das funções que a Constituição Federal lhes atribui, indevidamente atuarem em operações destinadas a "combater" o indefinido e indefinível "crime organizado" vulgarmente identificado em gangues que controlam o comércio varejista das drogas tornadas ilícitas em favelas. (KARAM, 2018, [s/p]).

Assentada essa premissa, o quadro é desolador, em nome dos "interesses da nação", do "combate à corrupção", da "manutenção da ordem pública", violam-se direitos e garantias fundamentais, sempre a apontar na direção do desaparecimento dos valores democráticos e dos correlatos limites rígidos ao exercício do poder. (CASARA, 2017).

Numa hipótese otimista em que a intervenção militar consiga prender todos os grandes traficantes. Vai extinguir o tráfico? Eliminar o consumo? Não são as drogas que causam violência, o que causa violência é a proibição. Preocupações verdadeiras com a segurança pública estão a exigir o debate em torno da regulação do comércio e consumo de drogas. Impostos serão pagos e recebidos pelo Estado, os recursos financeiros poderão ser investidos em ações voltadas para a promoção da saúde e da educação, policiais poderão se concentrar na prevenção e esclarecimento de crimes com vítimas, em vez de desperdiçarem suas vidas na inútil tentativa de conter um mercado que a história demonstra que não desaparecerá, ao menos pela via repressiva. (KARAM, 2018).

Por conseguinte, a situação gera foros de dramaticidade em terrae brasilis quando juízes e promotores assinam manifesto em apoio às Forças Armadas na intervenção do Rio de Janeiro, prontificando-se a colaborar com o sucesso do duro trabalho que será empreendido. (ARAÚJO, 2018).

A confusão entre acusação e julgador - o inquisidor pós-moderno - são sintomas do crescimento do pensamento autoritário, ao se identificarem acusador e juiz, o fato, o acontecimento, perde importância para a hipótese desde o início aceita como verdadeira, de modo que não há ou são muito reduzidas as chances de defesa (resistência). (CASARA, 2017).

Pois bem, quem julgará a legalidade ou as ilegalidades (violação dos direitos e garantias fundamentais) advindas dos atos da intervenção federal?

Destaca-se, neste ponto: fichamento da população (busca pessoal ausente de fundadas suspeitas); mandados de busca e apreensão domiciliar coletivo; impedimento do exército de que soldados sejam ouvidos como testemunhas pelo MP (chacina no complexo do Salgueiro); homicídios praticados em "virtude de legítima de defesa", os quais foram objeto de crítica pelo comissário Zeid Hussein da ONU; temos também o caso do churrasco dos "milicianos" (mais de 100 prisões e 18 denunciados pelo Ministério Público). (CHADE, 2018).

Os próprios atores jurídicos (ministros, procuradores, juízes, promotores, policiais etc.) do Sistema de Justiça Criminal, conforme assevera Casara (2017), não aceitam a existência de limites ao exercício do poder penal, de forma que estão dominados pelo verbo modal "poder".

Neste sentido, as declarações do Ministro Luís Roberto Barroso do Supremo Tribunal Federal ao afirmar que: "é preciso interpretar a Constituição em sintonia com o sentimento social." (ROXO, 2018, [s/p]).

O Poder Judiciário, ao menos nas democracias, deveria ser contramajoritário, isto é, para efetivar os direitos e garantias fundamentais, faz-se mister julgar contra a opinião das maiorias de ocasião forjadas na desinformação ou manipuladas por grupos de interesse. (CASARA, 2015). 
É o sentido contramajoritário, consoante Marcelo Semer (2018b), que permite ao Judiciário assegurar os direitos fundamentais, mesmo à revelia da população; que permite absolver réus indesejáveis, porque as provas juntadas aos autos não foram capazes de demonstrar suas culpas; que autoriza a concessão de liberdade a quem quer que esteja respondendo a um processo criminal, desde que não exista nenhum fundamento de perigo ao processo.

A vontade popular só pode ser encontrada nas palavras da Constituição, assenta Boujikian (2018), nenhum ente estatal pode substituir estas diretrizes pelas suas ou do que ele interpreta ser a vontade popular, ser juiz democrático é ter coragem para se contrapor aos barulhos das ruas, é saber que a sua submissão se encontra na Carta Cidadã.

O sentido contramajoritário, preconiza Semer (2018b) não mostra desprezo pela sociedade; ao revés, é um fator de proteção ao indivíduo, apenas no fascismo o "sentimento" da sociedade encontra guarida e, a pretexto de sua tutela, os indivíduos são simplesmente aniquilados. Tem-se, então, o que Casara (2017) denomina de "processo penal do espetáculo", isto é, a versão dirigida pelo juiz para agradar a opinião pública ou o desejo das corporações midiáticas sobre o fato.

Certa vez, uma pessoa emanou uma célebre frase: "Que teríamos feito sem os juristas alemães?". Esse mesmo sujeito, em 1938, foi escolhido o "homem do ano" pela aclamada revista norte-americana Time, elogiado acerca de sua luta contra a corrupção e o comunismo que "ameaçavam os valores ocidentais" - o líder nazista Adolf Hitler. (TIME MAGAZINE, 1939, tradução nossa).

Com o apoio da maioria dos meios de comunicação, que apoiavam o afastamento de limites legais ao exercício do poder penal, propagandeando uma justiça penal mais célere e efetiva, Hitler contou com amplo apoio da opinião pública, não só na Alemanha, sendo alçado à categoria de herói - um verdadeiro combatente ao "inimigo comum" e à "corrupção" - com o fito de resgatar os "valores tradicionais". (CASARA, 2016).

Hitler ofereceu soluções simplistas que, à primeira vista, faziam sentido para todos. O problema da violência, argumentava, poderia ser solucionado aplicando a pena de morte com mais frequência e aumentando as penas. Tudo foi arquitetado em slogans fáceis de lembrar: "Alemanha acima de tudo", "Renascimento da Alemanha", "Um povo, uma nação, um líder." (STUENKEL, 2018)

Referido discurso não parece familiar?!

O Holocausto foi possível apesar do Estado de Direito, pois o nazismo contou com a ajuda de juristas e juízes, aplicando a legislação do partido nazista, de modo que a opressão não é incompatível com o direito. (CASARA, 2017).

Desta feita, conforme bem pontua Casara (2016), ao contrário do que muitos ainda pensam, o projeto nazista não se impôs a partir do recurso ao terror e da coação, pois sempre que para o crescimento do Estado Penal Nazista era necessário afastar limites legais ao exercício do poder penal, "juristas" recorriam ao discurso de que era necessário ouvir o povo. O temor de juízes de desagradar a "opinião pública" é um fator que possibilitou violações aos direitos e garantias individuais homologadas pelos tribunais nazistas.

Percebe-se, pois, que só há Estado Democrático de Direito se os membros do Poder Judiciário forem dotados de coragem para fazer valer as "regras do jogo". Logo, quando a decisão judicial visa atender às maiorias de ocasião, não há Estado Democrático de Direito, mas mero simulacro. (CASARA, 2015).

Os processos que se legitimam pelo apoio popular, alerta Semer (2018b):

Tornam seus juízes celebridades instantâneas - mas produzirão sempre um protagonismo submisso, pois sua legitimidade depende do apelo do público e assim está vinculada a uma condenação, que o garante. O juiz condenado a condenar não julga - é réu de si 
mesmo. Em uma democracia constitucional como a nossa, juízes são garantidores de direitos. A Constituição lhes outorga esse poder; as maiorias os tornam reféns da política. O protagonismo não é apenas submisso, é também suicida. (SEMER, 2018b, $[\mathrm{s} / \mathrm{p}])$.

A Alemanha nazista como a Itália do fascismo clássico, salienta Casara (2017), apresentavam-se como um Estado de Direito, um estado autorizado a agir por normas jurídicas, vale dizer, a existência de leis nunca impossibilitou o terror. Aliás, a principal característica do Estado Democrático de Direito é justamente impedir violações a direitos como aquelas produzidas no Estado nazista, impondo limites que devem ser respeitados por todos, sobretudo pelo Poder Judiciário. (CASARA, 2017).

A "justiça penal nazista", portanto, instaurou-se às custas dos direitos e garantias individuais, estes percebidos por Hitler como empecilhos à eficiência do Estado e ao projeto de purificação das relações sociais, em nome dos superiores "interesses do povo". (CASARA, 2016).

Nada, ao menos nas democracias, legitima a relativização de uma garantia constitucional, como, exempli gratia, a presunção de inocência.

Sobre esta questão, o Supremo Tribunal Federal relativizou a conquista da presunção de inocência, direito fundamental, em contraste ao texto constitucional - livro quase em desuso nesses "novos" tempos -, e, à visto disso, transgrediu drasticamente a segurança jurídica e a unidade do Direito.

O que mais choca, aponta Boujikian (2018), são as violações a direitos e garantias oriundas do guardião (deveria ser) do sistema democrático - o Poder Judiciário - que tem o dever de salvaguardar o núcleo do Estado Brasileiro, os direitos fundamentais, os quais não admitem flexibilização alguma.

Até quando vamos assistir aos equívocos que são cometidos pelos membros do Poder Judiciário e achar que isso é comum? Culpa do estagiário, culpa do assessor, culpa do delegado, culpa do promotor, culpa do juiz, culpa do defensor, culpa do ministro, culpa do desembargador (...) e de quem é o dolo pela relativização de um direito fundamental? De quem é o dolo por estarmos ferrando (dia e noite) pobres e negros nas masmorras? Foram os grilhões substituídos por algemas? Foram as provas substituídas por convicção? (RAVAGNANI; GOMES; NEVES, 2018).

Usar o álibi da voz das ruas, ensina Semer (2018a), é um componente temerário, máxime para quem tem o múnus de zelar pela Constituição, até porque, em certos cenários, a Constituição tem justamente a função de defender o povo de si mesmo. Se se admitir, alerta Streck (2018), que o anseio popular vale mais que a Constituição, que vale mais que tudo, paradoxalmente, o Judiciário passa a ser dispensável.

O gosto pelo aplauso e reconhecimento, tão naturais aos imperadores romanos - estes, sim, combatentes - é consequência da posição apaixonada que se revela quando o juiz deixa a sua função e se torna combatente, o que nos faz namorar com a ditadura da toga e mergulha a todos nós nos destinos morais de uma nova inquisição. (BELLO FILHO, 2018).

Por certo, essa nova combinação sinérgica de significações gera drásticos efeitos no Sistema de Justiça Criminal, os acusados, na condição de inimigos, passam a ser meros objetos e não sujeitos de direitos de persecução penal, com o retorno do processo penal à lógica medieval. (CASARA, 2017).

Alexandre Morais da Rosa e Daniel Oliveira (2018) advertem que o nosso texto constitucional (ainda) consagra a combalida presunção de inocência, que deve ser alçada a um princípio supremo e concebida como um dever de tratamento para com o acusado. Ora, o que, de fato, se espera de um magistrado guiado por diretrizes de priorização da prisão, posto que a legislação processual estipula um controle muito maior acerca das decisões que entendam por soltar um acusado quando comparadas com as decisões de decretação de prisão? As possibilidades de recurso, voluntário ou de ofício se destinam a situações de defesa da liberdade, ao passo em que a manutenção ou deferimento da prisão não serão objetos de recursos. (ROSA, OLIVEIRA, 2018). 
Da mesma maneira que a ditadura instaurada em 1964 democratizou a tortura, o Estado PósDemocrático ampliou o âmbito de incidência do autoritarismo através de sintomas sociais que podem facilmente ser identificados na sociedade brasileira: crença em resposta de força, medo e desconfiança da liberdade, disposição a pensar mediante categorias rígidas (estereótipos), identificação com figuras de poder e hostilidade generalizada. (CASARA, 2017).

Muitas pessoas ainda não se atentaram, sustenta Semer (2018b), que a supressão indevida da liberdade de um réu - até aplaudem ao ver seus inimigos nas masmorras - é sempre um esvaziamento da liberdade de todos; outros tantos não compreenderam que quando os fins - o "combate" à corrupção justificam meios, todos serão ilegítimos.

Nesse sentido, frente ao cenário real enfrentado em terras brasileiras, faz-se necessário que se questione sobre um estado de exceção permanente, conforme escreveu Walter Benjamin:

A tradição dos oprimidos nos ensina que o "estado de exceção" em que vivemos é na verdade a regra geral. Precisamos construir um conceito de história que corresponda a essa verdade. Nesse momento, perceberemos que nossa tarefa é originar um verdadeiro estado de exceção; com isso, nossa posição ficará mais forte na luta contra o fascismo. Este se beneficia da circunstância de que seus adversários o enfrentam em nome do progresso, considerando como uma norma histórica. $\mathrm{O}$ assombro com o fato de que os episódios que vivemos no século XX “ainda” sejam possíveis, não é um assombro filosófico. Ele não gera nenhum conhecimento, a não ser o conhecimento de que a concepção de história da qual emana semelhante assombro é insustentável. (BENJAMIN, 1986, p. 226).

Não se pode olvidar que os direitos fundamentais, entendidos como os direitos de todos, não são dados da natureza, mas uma construção a partir de lutas políticas. A cada vez que um direito fundamental é violado ou relativizado, caminha-se um passo rumo ao autoritarismo. Com o desaparecimento dos limites ao exercício do poder, criam-se as condições pós-democráticas que se revelam adequadas a uma sociedade desumanizada desguarnecida de princípios. (CASARA, 2017).

O discurso verdadeiro, que a necessidade de sua forma liberta do desejo e libera do poder, não pode reconhecer a vontade de verdade que o atravessa; e a vontade de verdade, essa que se impõe a nós há bastante tempo, é tal que a verdade que ela quer não pode deixar de mascará-la. (FOUCAULT, 2009)

Nas lições de Walter Benjamin, é preciso o surgimento de um estado de exceção que enfrente aquele já permanente, onde a base teórica e jurídica será pautada nos direitos humanos fundamentais e na conscientização social.

\section{CONSIDERAÇÕES FINAIS}

Em tempos de relativização de direitos fundamentais, conclui-se que a adoção de "soluções" simplistas - utilização das Forças Armadas em tarefas de segurança pública, execução da pena em segunda instância - para fenômenos complexos como a criminalidade, o Brasil mergulha num cenário à margem do Estado Constitucional (Pós-Democrático), pois, em nome do combate ao "inimigo comum" (corrupção, impunidade e violência), afasta-se limites legais ao exercício do poder.

Através da tradição dos oprimidos, é possível constatar que os vencidos historicamente vivem num estado de exceção permanente, o que aplicado, por exemplo, à população carcerária brasileira, obtém sentido inconteste. Esse é o caminho no qual se instala um Estado de Exceção Permanente, de modo que como ensina Walter Benjamin, a forma de superar esse momento histórico, é reconhecer a tradição dos oprimidos e, de forma hermenêutica, atribuir valor e sentido ao texto constitucional que busca a emancipação de minorias excluídas, e valoração máxima do princípio da dignidade da pessoa humana. 
Em suma, deve-se reagir e resistir ao Estado Pós-Democrático, máxime no tocante ao agigantamento do Sistema de Justiça Criminal, caminho fértil e pavimentado para medidas absolutistas e antidemocráticas, notadamente em nome dos superiores "interesses do povo", do combate ao "inimigo comum", da manutenção da "ordem pública", da cessação do "sentimento de impunidade", do resgate aos "valores tradicionais", enfim, os direitos e garantias fundamentais - limites legais ao exercício do poder (ainda) precisam constituir-a-ação do projeto constitucional em terras brasileiras.

Por conseguinte, o Poder Judiciário - garante dos direitos fundamentais, trunfos contra o arbítrio e a opressão - não pode sucumbir e decidir movido por pré-juízos (que compõe o universo pessoal do julgador) ou apelos populistas, ainda que pressionado por maiorias de ocasião, grupos econômicos e políticos (a propósito, um jipe, um cabo e um soldado), efetivando-se seu papel contramajoritário, em estrita observância aos comandos constitucionais.

\section{REFERÊNCIAS}

ARAÚJO, V. Juízes e promotores assinam manifesto em apoio às Forças Armadas na intervenção do Rio. O Globo, Rio de Janeiro, fev. 2018. Disponível em: <https://oglobo.globo.com/rio/juizes-promotoresassinam-manifesto-em-apoio-as-forcas-armadas-na-intervencao-do-rio-22425403 >. Acesso em: 25 dez. 2018.

BELLO FILHO, N. de B. O Juiz combatente: a falácia da pós-modernidade. Justificando, ago. 2018. Disponível em: <http://www.justificando.com/2018/08/24/o-juiz-combatente-a-falacia-da-posmodernidade/>. Acesso em: 25 dez. 2018.

BENJAMIN, W. Crítica da violencia: crítica do poder. In: BENJAMIN, Walter. Documentos de Cultura, Documentos de Barbárie. Trad. Willi Bolle. São Paulo: Cultrix-Edusp, 1986.

BOUJIKIAN, K. O Estado Democrático de Direito e o Judiciário. Le Monde Diplomatique Brasil. São Paulo, nov. 2018. Disponível em: <https://diplomatique.org.br/o-estado-democratico-de-direito-e-ojudiciario/>. Acesso em: 25 dez. 2018.

BRASIL. MINISTÉRIO DA JUSTIÇA. Há 726.712 pessoas presas no Brasil. Brasília, DF, 2017. Disponível em: <http://www.justica.gov.br/news/ha-726-712-pessoas-presas-no-brasil>. Acesso em: 14 jun. 2018.

BRASIL. MINISTÉRIO DA JUSTIÇA. Levantamento Nacional de Informações Penitenciárias Atualização - junho de 2017. Organização, Marcos Vinicíus Moura. Brasília. Ministério da Justiça e Segurança Pública, 2017. Disponível em: <http://depen.gov.br/DEPEN/depen/sisdepen/infopen/relatoriossinteticos/infopen-jun-2017-rev-12072019-0721.pdf>. Acesso em: 20 ago. 2019.

CASARA, R. R. R. O estado pós-democrático: neo-obscurantismo e gestão dos indesejáveis. Rio de Janeiro: Civilização Brasileira, 2017.

CASARA, R. R. R. Democracia: coragem para manter as regras do jogo. Justificando, jul. 2015. Disponível em: <http://www.justificando.com/2015/07/04/democracia-coragem-para-manter-as-regras-dojogo/>. Acesso em: 25 dez. 2018.

CASARA, R. R. R. Vamos comemorar um tribunal que julga de acordo com a opinião pública?

Justificando, mar. 2016. Disponível em: <http://www.justificando.com/2016/03/12/vamos-comemorarum-tribunal-que-julga-de-acordo-com-a-opiniao-publica/\#contato>. Acesso em: 25 dez. 2018 
CHADE, J. Comissário da ONU critica intervenção federal no Rio. O Estado de S. Paulo, São Paulo, mar. 2018. Disponível em: <https://brasil.estadao.com.br/noticias/rio-de-janeiro,comissario-da-onucritica-intervencao-federal-no-rio,70002216992>. Acesso em: 25 dez. 2018.

FOUCAULT, M. A ordem do discurso. Aula Inaugural no Collège de France, pronunciada em 2 de dezembro de 1970. 19.ed. São Paulo: Edições Loyola, 2009.

LENZA, P. Direito constitucional esquematizado. 13. ed. São Paulo: Saraiva, 2009.

MAGALHAES FILHO, G. B. Hermenêutica e unidade axiológica da constituição. 3. ed. Belo Horizonte: Mandamentos, 2004.

RAVAGNANI, C. A; GOMES, L. G. C. B.; NEVES, B. H. O dolo eventual dos atores processuais em decisões penais arbitrárias. Revista Eletrônica de Direito Penal \& Política Criminal. Rio Grande do Sul, vol. 6, n. 2, p. 235-252, jul./dez. 2018. Disponível em:

<https://seer.ufrgs.br/redppc/article/view/87902/51578>. Acesso em: 30 dez. 2018.

RAVAGNANI, C. A.; POPOLIM, D. C. T. A (in)constitucionalidade busca judicial domiciliar pela Polícia Militar. Nucleus. Ituverava, v. 15, n. 2, out. 2018. Disponível em: <http://www.seer.ufu.br/index.php/revistafadir/article/view/39687>. Acesso em: 11 mar. 2018. http://dx.doi.org/10.3738/1982.2278.3016

RAVAGNANI, C. A; NEVES, B. H.; ITO, J. L. Pena de prisão: cerceamento da liberdade ou perda da dignidade humana?. Revista Jurídica Unigran. Dourados, vol. 19, n. 38, jul./dez. 2017. Disponível em: <http://www.unigran.br/revista_juridica/ed_atual/artigos/artigo07.pdf $>$. Acesso em: 11 mar. 2018.

ROSA, A. M. da; OLIVEIRA, D. K. de. Matriz autoritária como condicionante na atuação do julgador no processo penal. Revista Consultor Jurídico. São Paulo, dez. 2018. Disponível em:

$<$ https://www.conjur.com.br/2018-dez-21/limite-penal-matriz-autoritaria-condicionante-atuacao-julgadorprocesso-penal?utm_source=dlvr.it\&utm_medium=twitter>. Acesso em: 25 dez. 2018.

ROXO, S. Barroso diz que Constituição deve ser interpretada em 'sintonia com o sentimento social'. $\mathbf{O}$ Globo, Rio de Janeiro, abr. 2018. Disponível em: < https://oglobo.globo.com/brasil/barroso-diz-queconstituicao-deve-ser-interpretada-em-sintonia-com-sentimento-social-22549589>. Acesso em: 25 dez. 2018.

SEMER, M. O dono das ruas. Revista Cult. São Paulo, set. 2018. Disponível em: <https://revistacult.uol.com.br/home/luis-roberto-barroso-o-dono-das-ruas/>. Acesso em: 25 dez. 2018a.

SEMER, M. O juiz e o capitão: um projeto autoritário. Revista Cult. São Paulo, nov. 2018. Disponível em: <https://revistacult.uol.com.br/home/juiz-e-capitao-projeto-autoriatio/>. Acesso em: 25 dez. 2018b.

SILVA, J. A. da. Curso de direito constitucional positivo. São Paulo: Malheiros, 2006.

STRECK, L. L. Verdade e consenso: Constituição, hermenêutica e teorias discursivas da possibilidade à necessidade de respostas corretas em Direito. Rio de Janeiro: Lúmen Júris, 2008.

STRECK, L. L. Se Supremo deve obedecer à voz das ruas, qual é o valor da Constituição? Consultor Jurídico. São Paulo, abr. 2018. Disponível em: < https://www.conjur.com.br/2018-abr-28/observatorioconstitucional-stf-obedecer-voz-ruas-qual-valor-constituicao?utm_source=dlvr.it\&utm_medium=twitter $>$. Acesso em: 25 dez. 2018.

STUENKEL, O. Por que votamos em Hitler? El Pais Brasil, out. 2018. Disponível em: 〈https://brasil.elpais.com/brasil/2018/10/06/opinion/1538852257_174248.html?id_externo_rsoc=FB_CC> . Acesso em: 25 dez. 2018. 
TIME MAGAZINE. Adolf Hitlher: Man of the Year 1938. U.S., jan. 1939. Disponível em: <http://content.time.com/time/magazine/article/0,9171,760539-1,00.html>. Acesso em: 25 dez. 2018.

ZAFFARONI, E.R. El enemigo en el derecho penal. Buenos Aires, 2006. Disponível em: < http://www.geocities.ws/cindeunsch/doc/public/Zaffa03.pdf>. Acesso em: 20 ago. 2019. 